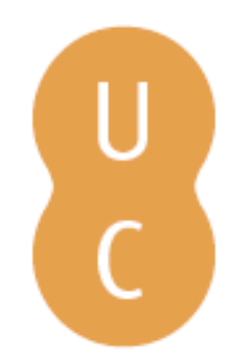

\title{
nombalina
}

A Primeira República e a imigração portuguesa em São Paulo: famílias e instituições

Autor(es): Demartini, Zeila de Brito Fabri

Publicado por: Imprensa da Universidade de Coimbra

URL

persistente: URI:http://hdl.handle.net/10316.2/35882

DOI: $\quad$ DOI:http://dx.doi.org/10.14195/978-989-26-0862-4_15

Accessed : $\quad$ 26-Apr-2023 11:11:54

A navegação consulta e descarregamento dos títulos inseridos nas Bibliotecas Digitais UC Digitalis, UC Pombalina e UC Impactum, pressupõem a aceitação plena e sem reservas dos Termos e Condições de Uso destas Bibliotecas Digitais, disponíveis em https://digitalis.uc.pt/pt-pt/termos.

Conforme exposto nos referidos Termos e Condições de Uso, o descarregamento de títulos de acesso restrito requer uma licença válida de autorização devendo o utilizador aceder ao(s) documento(s) a partir de um endereço de IP da instituição detentora da supramencionada licença.

Ao utilizador é apenas permitido o descarregamento para uso pessoal, pelo que o emprego do(s) título(s) descarregado(s) para outro fim, designadamente comercial, carece de autorização do respetivo autor ou editor da obra.

Na medida em que todas as obras da UC Digitalis se encontram protegidas pelo Código do Direito de Autor e Direitos Conexos e demais legislação aplicável, toda a cópia, parcial ou total, deste documento, nos casos em que é legalmente admitida, deverá conter ou fazer-se acompanhar por este aviso.

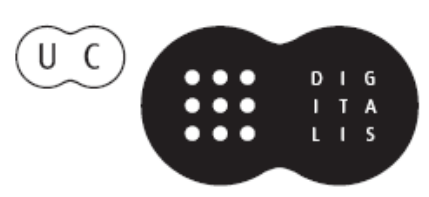




\title{
A EXPERIÊNCIA DA PRIMEIRA REPÚBLICA NO BRASIL E EM PORTUGAL
}

\author{
ALDA MOURÃO \\ ANGELA DE CASTRO GOMES
}

COORDENAÇÃO 


\section{A Primeira República e a imigração portuguesa em São Paulo: famílias e instituiçóes}

Zeila de Brito Fabri Demartini

Introdução

Tratar da Primeira República no Brasil envolve múltiplas perspectivas e possibilidades de análise sobre temáticas ainda só em parte estudadas; exige, também, que sejam considerados os diferentes contextos socioeconômicos e também culturais que precederam a proclamação e o período considerado de 1889 a 1930.

Focalizamos a imigração de portugueses para São Paulo durante a Primeira República (1889-1930). Consideramos que as vivências dos imigrantes neste período e neste contexto metropolitano em que conviveram com vários grupos de imigrantes europeus e orientais, juntamente aos demais grupos antigos da sociedade, carregavam especificidades que as diferenciavam das experiências em outros contextos socioeconômico-culturais.

A análise desse período da imigração portuguesa para São Paulo é importante porque foi então que ela ganhou grande vulto, chegando a superar, a partir de 1910, as correntes migratórias italiana, espanhola e japonesa, ainda muito fortes. Procuramos entender as vivências e estratégias deste grupo nesse contexto que passava por rápidas e profundas transformaçóes, assim como sobre a inserção das famílias por eles constituídas ao longo deste século. Para tanto, baseamo-nos em fontes diversificadas: relatos orais dos próprios imigrantes e de seus descendentes e documentação escrita pelo grupo no período considerado, especialmente jornais, revistas e estudos sobre o mesmo, além de dados oficiais. Abordamos: de um lado, as famílias desses imigrantes em suas 
vivências paulistanas, verificando por meio das experiências relatadas a diversidade das mesmas; os sonhos, expectativas, conflitos e estratégias desenvolvidas nesse novo contexto social; tratamos de aspectos relacionados à família, ao trabalho, à educação e à mobilidade; de outro lado, focalizamos algumas instituiçóes criadas pelo grupo durante o período considerado com atuação nos campos econômico, educacional, cultural e de lazer: Câmara Portuguesa do Comércio, Associaçáo Portuguesa de Desportos e Liga Propulsora da Instruçáo em Portugal. Tais elementos permitem visualizar algumas dimensões importantes da complexidade da imigraçáo portuguesa em Sáo Paulo na Primeira República.

As reflexôes aqui formuladas são fruto de estudos anteriores e já foram em grande parte abordadas em outros escritos (Demartini, 1989, 2001, 2002, 2003, 2006a, 2006b, 2010).

\section{O contexto paulista}

Em nosso estudo consideramos o contexto paulista e suas especificidades para refletir sobre a temática da Primeira República, acreditando que a análise de processos aí ocorridos permite contribuir para a incorporação de novos elementos na produção historiográfica sobre o período. Para tanto, selecionamos alguns aspectos que julgamos importantes: o contexto econômico paulista e as implicaçóes a ele relacionadas nos planos político e social.

A economia paulista, desde o início do povoamento português no século XVI até o século XIX, desenvolveu-se baseada em atividades variadas: o cultivo da cana-de-açúcar com a utilização da mão de obra indígena, e depois escrava, a agricultura de bens de consumo, o plantio de algodão, além das já famosas atividades das expediçóes de bandeirantes que capturavam índios para venda e das atividades ligadas aos tropeiros que, vindos do sul, percorriam a regiáo rumo principalmente a Minas Gerais, para a venda de seus produtos (carnes, animais etc.).

Só no século XIX é que o cultivo do café, que se iniciou no final do século XVIII pela faixa litorânea, ganhou força e subiu o planalto; o vale do Paraíba tornou-se o grande polo produtor desde a primeira metade do século, substi- 
tuído na segunda metade pelas novas regiôes do interior do estado, que apresentavam terras mais propícias à produção.

Até o final da Primeira República o café foi o produto de grande importância econômica, mas outras atividades também foram se expandindo, ligados a ele e ao crescimento dos povoados, como a produçáo de alimentos, subsistência, a criação e a construção de ferrovias para o transporte da produção; esta expandiu-se pelo estado, com linhas sendo constituídas cobrindo grandes extensóes, como as que ligavam o porto de Santos a várias regióes do interior do estado; muitas delas foram construídas com recursos particulares, visando o escoamento da produção das fazendas.

A expansão das ferrovias, iniciada em 1867 com a The São Paulo Railway, foi seguida, em 1968, pela Companhia Paulista de Estradas de Ferro e pela Companhia Mogiana de Estradas de Ferro em 1872. As ferrovias com seus ramais continuaram sua expansão durante o período republicano em direção às regióes novas do estado (Lang, 1995:25-26).

Alguns estudos realizados abordando o interior do estado de São Paulo já apontaram a diversidade das atividades econômicas aí desenvolvidas na segunda metade do século XIX.

Ribeiro (2005) mostrou o dinamismo da produção industrial na região de Americana, considerada regiáo nova, ao focalizar a indústria de tecidos Carioba, que aí funcionou a partir de 1875 , chegando a contar com centenas de empregados imigrantes, vários portugueses. No mesmo estudo, baseando-se também em análises de outros autores, observou que:

Na década de 1870, profundas transformaçóes marcaram a forma de expansão cafeeira na região, tais como: preponderância da mão de obra de imigrantes europeus; relativa mecanização do café que passou a ser beneficiado nas fazendas e aí armazenado, de forma mais lucrativa e moderna; um sistema de transporte mais eficiente se constitui com a construção das estradas de ferro: Companhia Paulista, Mogiana e Sorocabana, facilitando a remessa do café ao Porto de Santos; organização de um sistema de crédito que disponibilizava recursos não só para a produção de café, mas também para sua comercialização e exportação. Os lucros auferidos na economia cafeeira, organizada em moldes capitalistas, foram encaminhados em parte para o desenvolvimento da indústria do Estado de São Paulo (Ribeiro, 2005:29). 
Também Lisboa (2008) mapeou a produção econômica da regiáo de Sorocaba no século XIX, que se desenvolveu a partir das atividades dos tropeiros, chamando a atençáo para a importância dos donos de terra, controladores da vida econômica, social e política da regiáo e evidenciando, ao mesmo tempo, como as tradicionais parentelas procuravam acompanhar as transformaçóes em curso na sociedade e os processos de modernização econômica no campo e na cidade.

Como também constatamos em outro estudo sobre as relaçôes entre educação e populaçóes rurais em São Paulo, os fazendeiros paulistas interferiam nas decisóes das políticas de estado controlando, por exemplo, a distribuição e funcionamento das escolas de modo a atender seus interesses, mesmo no início do século XX (Demartini, 1989).

Foi nesse mesmo contexto de economia dinâmica e de sociedade em transformação que São Paulo manisfestou-se favoravelmente à instauração do regime republicano, bem antes da proclamação em 1889.

Em estudo importante em que mapeou a constituição do Partido Republicano de Sáo Paulo, Lang registrou o início do movimento republicano em 1872, quando decidiu-se pela organização de um partido republicano:

Ficou resolvida nesta reunião que em São Paulo seria organizado um partido republicano autônomo com relaçáo ao do Rio de Janeiro, de acordo com a forma federalista reivindicada para a República. A arregimentação dos aderentes seria feita através dos clubes republicanos dos municípios, em torno do clube da capital (Lang, 1995:29).

Segundo a autora, o objetivo era o de reunir as forças dispersas do estado:

Ficou resolvido que seria organizada uma reuniáo da qual participariam representantes de todas as localidades que quisessem aderir ao movimento. A cidade escolhida foi Itu e a data, 18 de abril de 1873. [...] Foram discutidas e aprovadas as bases para a organização do Partido Republicano da Província e a conveniência de se manter um jornal como órgáo do partido da Província, ou colaborar na imprensa republicana do Rio de Janeiro (Lang, 1995:29-30).

Conforme informa a pesquisadora, o congresso dos representantes das municipalidades deveria reunir-se anualmente, constatando que este ocorreu nos 
anos de 1873, 1874, 1878, 1880, 1881, 1882, 1883, 1884, 1885, 1887, 1888 e 1889 (Lang, 1995:31).

Um aspecto importante registrado no estudo é que a participação dos municípios (especialmente dos produtores de café) nos Congressos Republicanos foi crescente e significativa.

No ano de 1873 estiveram presentes representantes de 29 municípios dos 89 existentes na Província, o que correspondia a 33,5\%; em 1874 e 1878 eram 36 as localidades representadas. $\mathrm{O}$ grande impulso verificou-se em 1887, quando participaram 66 representantes, o que significava $60 \%$ dos 110 municípios então existentes; em 1888 e 1889 foram 67 os municípios representados (Lang, 1995:31).

A República em São Paulo esteve associada, desde seus primórdios, ao desenvolvimento da economia paulista baseada em grande parte na produção de café, mas não só. Do movimento republicano também participaram, além dos donos de terra, jornalistas, médicos, advogados, negociantes e outros profissionais. A propaganda contou com o apoio de jornais da capital e do interior, como A Província de Sáo Paulo (depois O Estado de S. Paulo), o Diário Popular, a Gazetta de Campinas, além de outros.

Outro aspecto interessante observado pela autora é que os depoimentos e relatos que analisou nunca fazem menção a um líder ou chefe, mas sempre à atuação e luta de um grupo, por alguns até chamados de "loucos" quando realizaram, em 1873, a Convenção Ituana, em plena monarquia (Lang, 1995:74). Até hoje, Itu mantém o Museu da República, em que comemoraçôes e eventos são realizados, constituindo-se num centro de visitação importante do estado de São Paulo.

Os representantes que participavam dos congressos tinham em sua maioria escolaridade elevada, vários sendo formados no exterior. Segundo Lang (1995:69), "os republicanos paulistas constituíam um grupo que se pode seguramente definir de letrado" e que "pertenciam à camada superior da sociedade".

A propaganda republicana abordou temas polêmicos no contexto paulista, como a libertação dos escravos e a imigração, questóes fundamentais em uma regiáo em que a máo de obra livre era cada vez mais demandada para o desenvolvimento econômico. 
Com a grande expansão da lavoura paulista, especialmente a cafeeira, também ocorreu grande crescimento e diversificação das indústrias, transformação das vilas e cidades, forte crescimento demográfico, urbanização intensa, entre outras mudanças que se intensificaram durante a Primeira República (Camargo, 1952; Silva, 1960).

Tratamos anteriormente de maneira sucinta de alguns aspectos da realidade paulista que, parece-nos, permitem considerar a necessidade de levarmos em conta as especificidades de cada contexto para uma melhor compreensáo da Primeira República brasileira. Dessa forma é que também consideramos fundamental incorporar na discussão a presença transformadora da imigração nesse contexto.

\section{A presença transformadora da imigração e os imigrantes portugueses}

Foi justamente durante a segunda metade do século XIX que começaram a entrar em Sáo Paulo os diferentes grupos de imigrantes, que vieram modificar e marcar a composiçáo da populaçáo paulista durante toda a Primeira República, assim como todos os setores da vida econômica, social e cultural da região.

É preciso chamar a atenção para o fato de que, historicamente, São Paulo recebeu os maiores contingentes de imigrantes (considerando o território brasileiro).

Algumas áreas, como se pode verificar pela tabela 1, constituíram-se como as principais áreas receptoras de imigrantes no Brasil: São Paulo, como vimos, seguido pelo Rio de Janeiro e estados do Sul. Segundo Bassanezi (1996), a região Sudeste foi a que concentrou as maiores proporçóes de estrangeiros. 
Tabela 1

População estrangeira nas províncias e estados brasileiros. Censos em 1872 a 1980

\begin{tabular}{|c|c|c|c|c|c|c|c|c|}
\hline Estados & 1872 & 1890 & 1900 & 1920 & 1940 & 1950 & 1970 & 1980 \\
\hline Alagoas & 3.718 & 536 & 838 & 693 & 511 & 421 & 524 & 606 \\
\hline Amazonas & 2.199 & 3.277 & 1.882 & 16.936 & 7.441 & 5.192 & 3.701 & 3.767 \\
\hline Bahia & 22.397 & 26.776 & 9.071 & 10.600 & 8.007 & 8.224 & 9.685 & 9.875 \\
\hline Ceará & 1.592 & 534 & 859 & 901 & 1.372 & 1.206 & 1.429 & 1.838 \\
\hline D. Federal & - & - & - & - & - & - & 4.584 & 7.920 \\
\hline E. Santo & 4.191 & 3.074 & 21.420 & 18.754 & 10.043 & 5.507 & 3.204 & 2.698 \\
\hline Goiás & 367 & 62 & 86 & 1.694 & 2.507 & 3.667 & 5.653 & 4.607 \\
\hline Maranhão & 5.247 & 606 & 939 & 1.586 & 1.288 & 1.008 & 1.070 & 1.135 \\
\hline M. Grosso & 1.669 & 958 & 11.167 & 25.321 & 23.207 & 19.753 & 24.937 & \\
\hline M. Grosso N. & & & & & & & & 3.033 \\
\hline M. Grosso S. & & & & & & & & 11.379 \\
\hline M. Gerais & 46.900 & 46.787 & 91.593 & 85.705 & 45.546 & 32.896 & 25.321 & 19.937 \\
\hline Pará & 6.529 & 4.039 & 2.201 & 22.083 & 11.074 & 8.215 & 8.866 & 7.294 \\
\hline Paraíba & 843 & 180 & 345 & 602 & 671 & 516 & 592 & 1.066 \\
\hline Paraná & 3.627 & 5.153 & 39.786 & 62.753 & 66.653 & 76.592 & 80.497 & 42.811 \\
\hline Pernambuco & 13.444 & 2.690 & 4.240 & 11.698 & 6.720 & 5.551 & 6.386 & 5.701 \\
\hline Piauí & 653 & 19 & 97 & 326 & 285 & 258 & 270 & 310 \\
\hline RJ-Guanab. & 184.182 & 140.492 & 246.272 & 289.960 & 267.367 & 248.849 & 283.742 & 216.266 \\
\hline R. G. Norte & 997 & 152 & 179 & 327 & 451 & 453 & 389 & 801 \\
\hline R. G. Sul & 41.725 & 34.765 & 135.099 & 151.025 & 109.470 & 78.138 & 51.079 & 36.813 \\
\hline S. Catarina & 16.974 & 6.198 & 29.550 & 31.243 & 27.201 & 19.067 & 10.188 & 7.496 \\
\hline S. Paulo & 29.622 & 75.030 & 478.417 & 829.851 & 814.102 & 693.321 & 703.526 & 523.444 \\
\hline Sergipe & 2.583 & 270 & 270 & 397 & 290 & 184 & 250 & 555 \\
\hline Acre & & & - & 3.506 & 1.236 & 1.144 & 704 & 551 \\
\hline Fer. N./Ap & & & & & & $2 / 504$ & $6 / 395$ & $-/ 339$ \\
\hline Roraima & & & & & & 2.094 & 1.837 & 663 \\
\hline Rondônia & & & & & & 420 & 299 & 1.943 \\
\hline Brasil & 389.459 & 351.545 & 1.074 .671 & 1.565 .961 & 1.405 .442 & 1.213 .182 & 1.229 .134 & 912.848 \\
\hline
\end{tabular}

Fonte: Levy (1974:13). In: Bassanezi (1996:13). 
Desde o século XIX, como se pode observar na tabela 2, as maiores levas vieram de Portugal, Itália, Espanha, Alemanha e Japão, embora também houvesse fluxos imigratórios procedentes da Rússia, Líbano, Áustria, Polônia, Hungria, Suíça, Lituânia, entre outros países.

Tabela 2

Entradas de imigrantes no Brasil: principais nacionalidades 1872-1972

\begin{tabular}{|c|r|r|r|r|r|r|r|}
\hline Período & \multicolumn{1}{|c|}{ Portugal } & \multicolumn{1}{c|}{ Itália } & Espanha & Alemanha & \multicolumn{1}{c|}{ Japão } & \multicolumn{1}{c|}{ Outros } & \multicolumn{1}{c|}{ Total } \\
\hline $1872-1879$ & 55.027 & 45.467 & 3.392 & 14.325 & - & 58.126 & 176.337 \\
\hline $1880-1889$ & 104.690 & 277.124 & 30.066 & 18.901 & - & 17.841 & 448.622 \\
\hline $1890-1899$ & 219.353 & 690.365 & 164.293 & 17.084 & - & 107.232 & 1.198 .327 \\
\hline $1900-1909$ & 195.586 & 221.394 & 113.232 & 13.848 & 861 & 77.486 & 622.407 \\
\hline $1910-1919$ & 318.481 & 138.168 & 181.651 & 25.902 & 27.432 & 123.819 & 815.453 \\
\hline $1920-1929$ & 301.915 & 106.835 & 81.931 & 75.801 & 58.284 & 221.881 & 846.647 \\
\hline $1930-1939$ & 102.743 & 22.170 & 12.746 & 27.497 & 99.222 & 68.390 & 332.768 \\
\hline $1940-1949$ & 45.604 & 15.819 & 4.702 & 6.807 & 2.828 & 38.325 & 114.085 \\
\hline $1950-1959$ & 241.579 & 91.931 & 94.693 & 16.643 & 33.593 & 104.629 & 583.587 \\
\hline $1960-1969$ & 74.129 & 12.414 & 28.397 & 5.659 & 25.092 & 51.896 & 197.587 \\
\hline $1970-1972$ & 3.073 & 804 & 949 & 1.050 & 695 & 9.017 & 15.558 \\
\hline $1872-1972$ & 1.662 .180 & 1.622 .491 & 716.052 & 223.517 & 248.007 & 878.642 & 5.350 .889 \\
\hline
\end{tabular}

Fonte: Levy (1974). In: Bassanezi (1996:8)

No Brasil, uma grande parte dos imigrantes dirigiu-se para as grandes fazendas de café. Segundo Petrone (1990), um número menor estabeleceu-se como pequenos proprietários nos núcleos coloniais dos estados do Rio Grande do Sul, Santa Catarina, Paraná e Espírito Santo, lembrando que também em São Paulo houve alguns núcleos e que muitos imigrantes preferiram localizar-se em cidades.

Segundo alguns estudiosos (Ianni, 1967; Prado Jr.,1953) para se entender os fluxos de imigrantes "livres" é preciso relacioná-los às transformaçôes do regime escravista no país. Especialmente a partir da extinção do tráfico, em 1850, começam a ser introduzidos trabalhadores livres de origem europeia (alemães, suíços-alemáes e portugueses) com o objetivo de substituir a mão de obra escrava. À medida que novas leis vão sendo aprovadas visando a extinçáo da escravidão (Lei do Ventre Livre e Lei dos Sexagenários), desenvolveu-se um 
interesse maior na substituição do negro pelo imigrante, tanto para o trabalho agrário como para as atividades urbanas. Segundo Azevedo (1987), estudiosa da escravidão no Brasil, os reformadores do século XIX, pautados na ideia de inferioridade de negros e mestiços, isto é, de grande parte da população brasileira de então, foram delineando um projeto que não estava desvinculado da ideia de construção de uma nação branca, o que só se tornaria viável com a introdução maciça de trabalhadores europeus.

Com a abolição da escravidão em 1888 (Lei Áurea) ocorreu a instituição integral do trabalho livre, acentuando-se a preocupação com o embranquecimento da população paralelamente às políticas de incentivo à imigração. Além dos problemas a serem enfrentados com negros e mestiços que se tornaram livres, aparecem claramente as preocupaçôes com a definição das correntes imigratórias desejáveis e indesejáveis. No início da República foi regulamentado o Serviço de Introdução e Localização de Imigrantes que estabelecia:

Artigo 1ํ-É inteiramente livre a entrada, nos portos da República dos indíviduos aptos para o trabalho, que não se acharem sujeitos à ação criminal do seu país, exetuados dos indígenas da Ásia ou da África, que somente mediante a autorização do Congresso Nacional poderão ser admitidos de acordo com as condiçôes que forem estipuladas (Decreto no 528, de 28/6/1890) (Vainer, 1996:43).

A demanda crescente por mão de obra imigrante acompanhou o desenvolvimento da economia brasileira, baseada na agricultura, e, como o café era o grande motor dessa economia, São Paulo foi a região que recebeu as maiores levas de imigrantes. Já em 1886 os fazendeiros paulistas fundaram a Sociedade Promotora da Imigração com a finalidade de promover a vinda de imigrantes para trabalhar nas fazendas (Petrone, 1990).

Com a instauração do governo republicano, pautado pelo federalismo, tentou-se colocar as políticas imigrantistas e de colonização sob a tutela dos estados. São Paulo beneficiou-se dessas medidas para estabelecer políticas próprias de atração de imigrantes; passou, assim, a desenvolver uma imigração subvencionada, por meio do pagamento de passagens aos imigrantes (embora nem todos fossem desejáveis). Durante as primeiras décadas do século $\mathrm{XX}$, vieram não só os imigrantes subsidiados pelo governo paulista, que desenvolvia juntamente com os cafeicultores, principalmente nos países europeus, propa- 
ganda para atraí-los, mas também outros que vinham por conta própria. $\mathrm{Na}$ base da propaganda, estava a imagem de que em São Paulo poderiam tornar-se ricos. Vendia-se a imagem de que poderiam "fazer a América", que nessa regiáo havia uma planta — o pé de café — que tinha "grãos de ouro", que era a "árvore das patacas" etc.

Ao mesmo tempo, as dificuldades enfrentadas pelos países de origem (Itália, Portugal, Espanha, Alemanha, Japão etc.) permitiram não só que a propaganda conseguisse atrair interessados, mas até que os imigrantistas quisessem selecionar os imigrantes desejáveis: isso é, os brancos provenientes de países europeus (mas não de Portugal, e menos ainda do Oriente). Mas vieram imigrantes de diferentes origens, até os considerados indesejáveis. A política de atração de imigrantes para o trabalho na lavoura foi diminuindo durante os anos de 1920 e a partir de 1930 atos do governo central limitaram e disciplinaram a entrada de estrangeiros (Petrone, 1990).

Entre os diferentes grupos de imigrantes que vieram desde o século XIX, predominaram portugueses, italianos, espanhóis, japoneses, alemães. A tabela 3, abaixo, permite visualizar essas presenças em São Paulo.

Tabela 3

Estrangeiros no estado de São Paulo, segundo a nacionalidade (1888 a 1980)

\begin{tabular}{|l|c|c|c|c|}
\hline NACIONALIDADE & 1888 & 1920 & 1940 & 1980 \\
\hline Portugueses & 9.853 & 167.198 & 155.251 & 174.089 \\
\hline Japoneses & - & 24.435 & 128.957 & 89.361 \\
\hline Italianos & 13.384 & 398.797 & 213.091 & 60.280 \\
\hline Espanhóis & 1.003 & 171.289 & 121.162 & 57.369 \\
\hline Alemães & 4.838 & 11.060 & 33.397 & 15.474 \\
\hline Outros & 7.747 & 57.072 & 110.133 & 126.871 \\
\hline Subtotal & 29.078 & 772.779 & 651.858 & 396.573 \\
\hline TOTAL & 36.825 & 829.851 & 761.991 & 526.444 \\
\hline
\end{tabular}

Fonte: ATLAS da população do estado de São Paulo (1991).

Assim, como já constatamos em vários estudos, a imigração é constituinte da história de São Paulo; foram levas de pessoas que entraram durante muitos anos, carregando consigo as vivências e as culturas das sociedades de origem.

O que é importante destacar é que a imigração portuguesa foi muito grande no estado de São Paulo, superando a entrada de italianos no século XX; 
nesse estado, os imigrantes portugueses conviviam com imigrantes de várias origens, no campo e nas cidades, em atividades variadas (agrárias, comerciais, industriais etc.). Segundo alguns estudiosos, pode-se dizer que as atividades agrárias, o trabalho direto na terra não era o objetivo inicial deste grupo, historicamente; mas sim o comércio, visto como forma de enriquecer (Serrão, 1971:64)

Alguns elementos devem ser considerados quando se pensa nas trajetórias dos portugueses no campo econômico. Parece-nos que a inserção do imigrante português nas atividades econômicas em São Paulo durante a Primeira República merece uma reflexão que extrapola a dimensão propriamente econômica. É que os documentos e escritos de outros pesquisadores dão indicaçóes de que os imigrantes portugueses, em virtude do tipo de atividade que muitos deles desenvolveram (geralmente o comércio a retalhos), provocaram no Brasil reaçóes da população nacional que foram impregnando as representaçôes sobre esses portugueses e construindo ao longo do século XIX uma imagem negativa de sua atuaçáo no plano econômico. No imaginário deste período, parece serem correntes as imagens de que estes imigrantes chegavam sem capital, só se dedicavam aos negócios e, depois de conseguirem acumular ganhos significativos, voltavam para Portugal (Silva, 1992:XVIII, XIX). A tensão cultivada durante o século XIX teria persistido ainda com o advento da República, segundo Silva (1992:XIX-XX):

A recém-criada República brasileira, em instável situação política e econômica, fez dos portugueses o seu bode expiatório: como detinham o comércio de retalho, eram acusados de subir os preços das mercadorias; como possuíam propriedades imobiliárias na cidade, sobretudo "cortiços", eram responsabilizados pelo aumento dos aluguéis. E a revolta da Marinha recaiu também sobre a colônia, tendo o Marechal Floriano rompido relaçôes diplomáticas com Portugal.

Não se tratava mais de uma simples malquerença, de um preconceito da população contra os portugueses. $\mathrm{O}$ conflito subira à esfera política e por isso jornais como "A União Portuguesa", do Rio Grande do Sul, aconselhavam a total abstenção da política brasileira.

Para a autora (Silva, 1992:XXI), a situação de maior conflito teria surgido quando, em grandes cidades, os imigrantes portugueses apareciam como economicamente poderosos e bastante integrados na vida nacional. 
Também Ribeiro (1990) já havia chamado a atenção para tal fato em seu clássico estudo (Mata galegos) sobre os portugueses:

Os portugueses foram os bodes expiatórios responsabilizados pelas crises econômicas da República iniciante. Eram considerados culpados e acusados de explorarem a população cobrando aluguéis extorsivos e juros alucinantes sobre dinheiro emprestado, bem como roubando nos pesos e medidas nas vendas, freguês, botequins, quiosques e casa de pasto. Caracterizados como intermediários, pesavam-lhes sobre os ombros a carestia e a vida surrada das camadas populares (Ribeiro, 1990:13).

A divulgação destas ideias era comum na imprensa diária (Ribeiro, 1990:14). A denominação de galego atribuída aos portugueses aparece no discurso jornalístico num sentido pejorativo (Alencastro e Renaux, 1990:312).

As atividades econômicas que permitiam o táo desejado enriquecimento criaram ao mesmo tempo problemas tanto com relaçáo à populaçáo nacional, que desenvolveu atitudes antilusitanas, como com relação à própria colônia, que também não via bem os que se integravam intensamente à vida brasileira como forma de garantir seus "ganhos". Segundo Silva (1992), embora tendo diminuído no início deste século, o antilusitanismo teria permanecido latente no século XX. Este foi também um dos fatores que teria criado restriçôes à vinda do imigrante português, que não era para muitos nacionais o "branco europeu” tão procurado. É preciso observar, entretanto, que não sabemos o que de fato ocorreu em São Paulo, pois nossos dados não evidenciaram tais conflitos entre os portugueses e os nacionais (lembrando que na metrópole de Sáo Paulo os imigrantes de várias nacionalidades constituíam grande parte da população).

O que podemos constatar é que, se os negócios urbanos eram os que causavam as maiores resistências aos portugueses, eram justamente estes os que eram estimulados pelo próprio governo português (ao contrário da política imigrantista brasileira, a quem interessava no início da República o imigrante que fosse trabalhar na lavoura). Assim, as várias Câmaras Portuguesas de Comércio, espalhadas pelo Brasil (em São Paulo foi criada em 1912), teriam feito a apologia das atividades mercantis. Segundo seus ideólogos, a atividade mercantil era a única através da qual se mantinham os elos firmes com a pátria de origem: 
Inquestionavelmente, o que mais convém a Portugal é:

1) que o emigrante português consuma no Brasil produtos portugueses;

$\left.2^{\circ}\right)$ que volte à sua pátria e lhe dê, também, seus filhos;

$\left.3^{\circ}\right)$ que mande dinheiro para Portugal (Silva, 1992:68-69).

As remessas de dinheiro dos imigrantes foram importantes para o governo português, neste período.

Quanto à atuação dos imigrantes portugueses nas indústrias que já se expandiam em São Paulo, como vimos, pouco há na literatura voltada para ela e para o desenvolvimento urbano-industrial. Os dados a este respeito parecem-nos dispersos, mas algumas observaçóes obtidas em pesquisas realizadas merecem ser anotadas, para que se compreenda a atuação deste grupo nas atividades econômicas da metrópole.

Embora muitos portugueses tenham se dedicado às atividades agrárias (Campos, 2003), observamos que muitos dos que vieram para São Paulo não se declararam agricultores em seu processo imigratório: no período de 1908 a 1936, teriam entrado pelo porto de Santos 131.545 agricultores (cerca de $47,79 \%$ do total), enquanto 13.158 se declararam artistas e 130.554 com outras ocupaçôes (D.T.C.I., 1937:74). Como se vê, já na chegada a porcentagem dos que se declaravam não agricultores superava a de agricultores.

Frutuoso (1989) também observou que o comércio foi o setor privilegiado pelos portugueses que chegaram às cidades paulistas, ficando conhecidos o bar, a padaria e a quitanda do português. A autora apontou também as profissóes mais comuns entre 1913 e 1915: açougueiros, ajudantes de cozinha, cozinheiros, alfaiates, caixoteiros, caldeireiros, carpinteiros, carroceiros, condutores de bonde, "chauffers", empregados no comércio, marceneiros, mecânicos, operários e apenas um carteiro (Frutuoso, 1989:109).

Os dados econômicos referentes à última década da Primeira República indicam que havia no estado de Sáo Paulo mais de 100 mil pessoas dedicadas a atividades industriais (fábricas e pequenas oficinas), sendo mais da metade destas estrangeiras; também elevada era sua participaçáo nos setores de transportes e de comunicação. Embora em grande parte fossem de origem italiana, também os imigrantes portugueses aí estavam representados; em relatório sobre as condiçôes de trabalho na indústria têxtil da capital, realizada em 1912, pelo Departamento Estadual de Trabalho, observou-se que do total de 10.204 ope- 
rários classificados, a maior parte era constituída por italianos (6.044: 59\%) e 824 (8\%) eram portugueses, havendo apenas 1.843 brasileiros natos; como se vê, se eram poucos quando comparados aos italianos, eram, entretanto, uma presença forte se comparados com os nacionais. Mais significativa era sua presença entre os braçais dos serviços públicos da capital: para 871 nacionais havia 1.408 estrangeiros (20 de nacionalidade ignorada), dos quais a maior parte era constituída por portugueses (865), seguindo-se os italianos (320) e espanhóis (165) (Fausto, 1976:29-30).

A presença dos portugueses em atividades diversas também fica evidente quando analisamos o levantamento realizado pela Diretoria de Terras, Colonização e Imigração de São Paulo sobre os acidentes de trabalho ocorridos na capital no ano de 1916, considerando a nacionalidade dos envolvidos, em que se constata que havia acidentados portugueses nas mais diversas atividades, e, em algumas delas, em maior número; apresentaram frequência alta em atividades urbanas como: carpinteiros, carroceiros, empregados no comércio, guardas cívicos, serviços domésticos, padeiros, operários, pedreiros, motoristas, jardineiros, leiteiros, além de trabalhadores e empregados sem especificação (o levantamento não discrimina o total de indivíduos por profissão e nacionalidade) (D.T.C.I., 1916).

O contexto paulistano, como já constatamos em outros estudos (Demartini e Espósito, 1989), apresentava-se aos imigrantes ao mesmo tempo como propiciador de possibilidades de êxito econômico, em virtude de uma oferta de trabalho crescente, o que em parte explica a inexistência de uma xenofobia manifesta permanente com relação a eles, mas também como campo de disputa por melhores empregos. Não podemos esquecer que o afluxo de imigrantes durante este período para a capital foi muito intenso, o que permitia uma seleção pautada em requisitos de qualificação por parte dos empregadores. Nesta disputa, se os imigrantes portugueses chegaram "tardiamente" a São Paulo e, se em sua grande maioria eram considerados "desqualificados" tanto no que se refere à educação escolar quanto à experiência anterior em atividades industriais e de serviços, parece que apresentavam uma qualidade que pode ter favorecido sua aceitação nestas mesmas atividades: eram considerados "dóceis", "docilidade" que pode ter sido uma estratégia para poderem ser aceitos neste mercado tão disputado. É o que parecem nos sugerir as observaçóes de Boris Fausto (1976:35-36) a respeito da baixa participação política destes imigrantes: 
Os portugueses eram tidos em São Paulo, pelos organizadores do movimento operário como elementos dóceis, destituídos de consciência de classe, uma visão que seu comportamento muitas vezes confirmava. Sem dúvida, a menor propensão dos portugueses a organizar-se, constatada sobretudo na Capital, relacionava-se em algum grau com sua experiência prévia. Enquanto os italianos vinham de regiôes em que os sindicatos começavam a surgir ou os movimentos milenaristas deixavam marcas, os portugueses se originavam de uma área bem mais atrasada no contexto europeu. Entretanto, se foram menos reivindicativos, se engrossaram por vezes as fileiras dos "krumiros", isto se deve em grande parte, como observa Maram, ao fato de que constituíam um grupo de baixa qualificação, tardiamente chegado a São Paulo, tendo de lutar em condições desiguais pelos limitados empregos ocupados pelos italianos. Em Santos, onde eram maioria ao lado dos espanhóis, estiveram entre os principais responsáveis pelas frequentes paralisaçóes da área portuária.

Também em nossas pesquisas entrevistamos uma família portuguesa que participava ativamente do movimento operário do período, na capital paulista.

Os portugueses foram, por outro lado, também valorizados por sua capacidade de trabalho, pois queriam enriquecer para poderem retornar a sua terra natal (Ribeiro, 1990:17). Nesse sentido, não se diferenciavam dos demais grupos de imigrantes com os quais conviviam em São Paulo, no interior e na capital, na segunda metade do século XIX e primeiras décadas do XX.

Apesar das representaçóes da população sobre o imigrante português residente nas cidades, de que era dócil e não participava dos movimentos operários, de que só queria enriquecer e voltar para Portugal, sendo concorrente no mercado de trabalho, sabemos que no período considerado já havia em São Paulo imigrantes portugueses estabilizados economicamente e até em ótimas condições financeiras, que tinham uma forte vinculação com a sociedade local, ao mesmo tempo que exerciam influências dentro da colônia portuguesa.

Camargo (1952:236-237), em análise realizada sobre o crescimento da população e seus aspectos econômicos, nota que já no início do século os portugueses predominavam como proprietários rurais no município da capital, onde especializaram-se na horticultura e floricultura com base na pequena propriedade localizada na parte suburbana da cidade (só no início do período seu número era inferior ao dos italianos). 
Também observa que os estrangeiros detinham, em 1920, grande parte dos estabelecimentos industriais do estado de São Paulo (64,2\%); os italianos eram os mais empreendedores, representando $75 \%$ do total dos proprietários estrangeiros; mas a eles seguiam-se, em São Paulo, os portugueses, espanhóis, sírios e alemães. Os portugueses mantiveram a segunda colocação também em 1940 (Camargo, 1952:258-259). O imaginário popular e os estudiosos sempre se referem aos italianos quando tratam de imigrantes que durante este período fizeram grandes fortunas. Mas também entre os portugueses vamos encontrá-los; o que se pode observar, neste caso, é que dificilmente vieram de Portugal desprovidos de algum capital anterior: ou eram de famílias com recursos, socialmente já reconhecidas, ou eram profissionais que aqui se aliaram a famílias da elite local, como constatamos entre algumas famílias que entrevistamos.

Desta forma, náo podemos pensar nos imigrantes portugueses deste período apenas como trabalhadores nas fazendas ou como empregados no comércio, na indústria e em outros serviços; suas atividades econômicas eram diversificadas: havia proprietários rurais, comerciantes e industriais de origem portuguesa já com muitos recursos, assim como imigrantes muito pobres disputando trabalho e tentando sobreviver, nas mais diferentes atividades: agrárias, comerciais, industriais e nos serviços em geral, como pudemos observar nas pesquisas que realizamos no Centro de Estudos Rurais e Urbanos (Ceru).

É interessante notar que quando foi fundada em São Paulo a Sociedade Portuguesa de Beneficiência, ainda em meados do século XIX (1859), consta que, entre 123 sócios fundadores, 44,7\% eram negociantes e 29,2\% caixeiros, havendo também: guarda-livros, farmacêuticos, alfaiates, artistas, atores dramáticos, barbeiros, charuteiros, doutores, latoeiros, leiloeiros, padeiros, pedreiros, professores, sapateiros, seleiros, tamanqueiros, tropeiros, além dos que se intitularam genericamente de capitalistas ou proprietários (Silva, 1992:48). Deste período para o início do século, com a grande imigração da Primeira República, parece-nos que a diversidade de atividades exercidas pelos imigrantes portugueses acentuou-se, assim como se abriram maiores possibilidades de inserção na economia paulista.

A presença de um mercado consumidor em expansão em São Paulo, assim como de muitos empreendedores de origem portuguesa, como já nos referimos, parece ter levado à criação da Câmara Portuguesa do Comércio de São Paulo em 1912. Esta representou, neste período, o mais importante elo entre 
os imigrantes portugueses e a "Pátria-Mãe", embora inicialmente criada mais para atender os interesses desta última que dos próprios imigrantes.

A Câmara Portuguesa do Comércio, Indústria e Arte, como era sua denominação primeira, tinha como fins principais, conforme consta da Ata de sua constituição (Boletim de janeiro de 1919):

Artigo $1^{1}$ - Com a denominação de Câmara Portuguêsa de Comercio, Industria e Arte, com séde na Cidade de S. Paulo dos Estados Unidos do Brasil, é constituída uma associação comercial, industrial e artistica, cujos fins principais são:

a) - Defender e promover o desenvolvimento das relaçóes comerciais entre Portugal e Brasil;

b) - Tornar conhecida aos seus socios e em Portugal a Legislação Comercial do Brasil e suas tarifas alfandegarias bem como as sucessivas modificaçóes nelas feitas;

c) - Informar os diferentes processos de compra e venda, denunciar e reprimir as fraudes, contrafacçôes, usurpações de marcas e designações de falsa procedencia que possam ser cometidas em prejuizo dos produtos portugueses;

d) - Procurar conciliação, quando solicitada, nas questôes comerciais, servindo de arbitro entre portugueses, ou entre estes e estrangeiros;

e) - Corresponder-se com as autoridades brasileiras e bem assim com as associaçôes comerciais, industriais e agricolas estabelecidas no país;

f) - Promover na cidade de S. Paulo exposiçóes de propaganda de produtos portugueses;

g) - Organizar estatisticas que interessem ao comercio e industria portugueses, nas suas relaçóes com o Brasil e publicá-las em Boletim mensal, registrando ao mesmo todas as informaçōes que interessem á associação;

h) - Nomear delegados nas cidades do Estado de S. Paulo onde não haja Câmara Portuguêsa de Comercio;

i) - Trabalhar no sentido do estabelecimento de uma carreira de navegação entre Portugal e o Brasil, prestar-lhe todo o apoio, e, quando levada a efeito, promover o seu progresso;

j) - Defender os interesses das classes representadas pelos seus associados;

k) - Esforçar-se por agremiar todos os portuguêses, podendo criar, anexo á Câmara, um 'Centro da Colonia Portuguêsa' privativo dos seus socios, com salas de leitura, de reunião, de sessóes literarias e artisticas.

Artigo 2o - Para a consecução dos fins, a Câmara manterá com o Governo Português, correspondendo-se dirétamente com os Ministros, agentes diplomaticos, 
consules, associaçóes comerciais, industriais e agricolas, e outras, não só da metrópole como estrangeiras.

Artigo 3o - Á Câmara Portuguêsa de Comercio, Industria e Arte é expressamente proibido tratar e discutir assuntos que não se refiram aos fins sociais (80 Anos, 1992:51-52).

A Câmara Portuguesa de Comércio de São Paulo, desde sua fundação, tentou colocar em prática seus propósitos, embora se enfrentassem naquele momento a crise provocada pela Primeira Guerra Mundial e também os problemas da situação política de transição da Monarquia para a República em Portugal, recém-instituída. O café enfrentava restriçóes no plano mundial, o que atingia diretamente os destinos dos imigrantes portugueses que para cá vieram, fugindo da situação precária em Portugal. Esse período foi lembrado nas comemoraçóes dos 80 anos da Câmara:

Não era, portanto, um ambiente de serena e geral prosperidade que entâo se vivia em São Paulo. Os portugueses que mais poderosamente poderiam influir no desenvolvimento da Câmara eram comerciantes e industriais. Estavam diretamente abrangidos pela situação e deveriam tomar, com a segurança que lhes era peculiar, todas as cautelas em custear entidades associativas, na incerteza de necessitarem dos seus capitais para investimentos em atividades rentáveis ou para colmatar brechas resultantes da situaçáo geral. O conflito de 1914/18 provocara o bloqueio do fluxo de mercadorias e de capitais para o Brasil, afinal o único país da América do Sul a declarar guerra ao império alemão.

Não nos parece, pois, de estranhar que, precavidos, aguardassem os portugueses de São Paulo - e não só - melhores oportunidades, mais propícias a rasgos de generosidade para a sustentação de associações ou de clubes, ainda que o alcance da Câmara fosse diretamente relacionado com as atividades econômicas a que se dedicavam.

No entanto, a Câmara Portuguesa de Comércio de São Paulo não deixava de estar atenta, nos limites das suas possibilidades, ao cumprimento da funçáo que assumira espontaneamente, e em Março de 1914 dirigiu-se ao governo português, à Associaçáo Comercial de Lisboa e à União de Agricultura, Comércio e Indústria, entre outras entidades, sobre o interesse de se criarem estabelecimentos bancários portugueses no Brasil [...]

[...] Parece que a sugestão foi ouvida, porque em 1915 o Banco Nacional Ultramarino, não obstante as contingências da época, estabeleceu-se no Rio de Janeiro 
e nos princípios de 1916 em São Paulo, na rua 15 de novembro. Ao publicar o balancete do Banco Ultramarino referente a Novembro de 1915, o Boletim da Câmara comentava, em artigo assinado por J. Amorim: “...até poucos tempos atrás, apesar do intercâmbio do Brasil e Portugal alcançar anualmente cifra superior a 65.000 contos fortes, os portugueses aqui residentes lutavam com dificuldades e tinham de ir deixar o lucro das transferências a entidades estranhas". [...] Havia, portanto razóes para não desistir do diálogo dos portugueses de São Paulo com a máe pátria e, apesar de todo o panorama geral refletir a situação decorrente da guerra na Europa, Manuel de Barros Loureiro, ao assumir a presidência da Câmara em 1915, vem imbuído de serena capacidade realizadora e disposto a colocá-la ao serviço de um esclarecimento que se entendia necessário às boas relaçóes econômicas que tanto convinham aos importadores paulistas como deviam interessar aos industriais e exportadores de Portugal. (80 Anos, 1992:52-53)

Portugal tinha grande interesse em ampliar seus vínculos com São Paulo, especialmente neste período em que as condiçóes econômicas e políticas naquele país eram tấo precárias. A fala do segundo presidente da Câmara em 1915 é bem clara quanto a seus objetivos:

Mas talvez agora [...] possamos conquistar um mais largo terreno na ocupação destes mercados, adotando um plano de propaganda a favor dos nossos principais produtos, vinhos, azeites, conservas e frutas, e fazendo deles uma inteligente e persistente apresentaçấo. Cabe perfeitamente na índole das Câmaras de Comércio o estudo das medidas a adotar [...]

[...] E corroborou que as Câmaras de Comércio [...] poderão fornecer ao Governo Português preciosas informaçôes que facilitem a apreciação das condiçôes em que os nossos produtos devem concorrer com os similares estrangeiros. Os Cônsules [...] hão de esclarecer e guiar os nossos comerciantes em Portugal na exploração destes mercados [...] (80 Anos, 1992:54).

É importante observar, entretanto, o posicionamento dos participantes da Câmara de São Paulo com relação aos comerciantes de Portugal, indicando certa autonomia em relação à "Pátria Mãe":

E lembre esta Câmara aos nossos comerciantes em Portugal que os velhos moldes em que outrora assentavam as negociaçóes comerciais foram afastados, que os 
mercados do Brasil, hoje, têm exigências, impostas pelo seu progresso, que se torna urgente satisfazer; e lembre-lhes, por último, que as geraçóes atuais [...] estấo empenhadas, numa corrente cada vez mais forte e incontrariável, por tornar o Brasil a mais poderosa das Nações Sul-Americanas (80 Anos, 1992:54).

A Câmara procurava realizar exposiçóes de produtos portugueses em sua sede, onde havia vitrines especialmente construídas para tanto. Também publicava nos jornais de Lisboa e do Porto anúncios sobre as vantagens que o momento oferecia aos industriais portugueses no mercado brasileiro. Com relação à sua inserção mais ampla, a Câmara participou intensamente das comemoraçóes do Centenário da Independência, em 1922, tendo um de seus mais importantes membros, Ricardo Severo, ficado encarregado do "Pavilhão das Indústrias Portuguesas".

Durante o período republicano, muitas outras instituições ligadas aos imigrantes portugueses funcionavam em São Paulo. Assim, na Revista Portuguesa de 1929 verifica-se que as Sociedades Portuguesas de caráter econômico, beneficente e artístico existentes no distrito consular de São Paulo eram já numerosas, além da Câmara Portuguesa de Comércio:

Sociedade Portuguesa de Beneficência de São Paulo, Sociedade Portuguesa Beneficente Vasco da Gama, Caixa Portuguesa de Repatriação, Sociedade Protetora dos portugueses desvalidos, Liga Propulsora da instrução em Portugal, Associaçáo Socorros Mútuos Sacadora Cabral Gabo Coutinho, Portugal Clube, Clube Português, Centro Republicano Português, Liga monárquica Dom Manoel II, Grêmio Português de Beneficência, Sociedade Portuguesa de Beneficência, Sociedade Portuguesa Beneficente, Sociedade beneficente Portuguesa, Caridade Portuguesa Maria Pia, Sociedade Portuguesa de Beneficência Campinas (Revista Portuguesa, 1929:319).

Tais instituiçôes e os intelectuais da colônia procuravam estimular a participação dos imigrantes em atividades culturais e ampliar sua escolarização, mas foram poucas as concretizaçóes realizadas no campo educacional, no tocante à manutenção de escolas do próprio grupo. Como pudemos constatar, foram criadas poucas escolas, embora muitos portugueses exercessem atividades docentes (Demartini, 2010). Por outro lado, os imigrantes portugueses mobili- 
zaram-se para criar escolas no seu contexto de origem, fato que não conseguimos constatar entre nenhum outro grupo que veio para São Paulo.

A Revista Portuguesa noticiava e destacava em 1929, quando a colônia aqui já era numerosa, a criação de uma associação para cuidar da educação em Portugal:

Aos cinco dias do mês de janeiro de 1925 fundou-se na Câmara Portuguesa de Comércio de São Paulo a Liga Propulsora da Instrução em Portugal. Beneficente lhe tem chamado uns. Altruísta lhe tem chamado todos. Fonte de vida lhe chamaremos nós. [...]. A Liga Propulsora da Instrução em Portugal, que muito deve ao poder criador, ao esforço orientado, à visão clara e à lúcida inteligência de Antônio da Silva Parada, é uma grande obra. [...] (Revista Portuguesa, 1929:234).

Desenvolver a educação em Portugal constituiu-se no grande investimento educacional da comunidade portuguesa de São Paulo neste período. A explicação para este fato, a nosso ver, é que grande parte dos imigrantes, quando para cá vieram, não rompeu os fortes vínculos familiares. As estatísticas oficiais mostram que a maioria eram homens e vinham sozinhos, deixando mulheres e filhos em Portugal. A preocupação com o país de origem não tinha assim só razóes de fundo patriótico-nacionalista, mas concretas na medida em que os familiares lá continuavam morando em situação geralmente precária, necessitando do apoio dos que imigravam; o retorno, especialmente no caso da imigração portuguesa, era estimulado pelo próprio governo português como forma de garantir o envio dos recursos obtidos pelos imigrantes para suas famílias. Acompanhando este fato de que muitos vieram "avulsos" (53\% dos que vieram entre 1908 e 1936), a distribuição dos imigrantes por idade evidencia que a maior parte tinha mais de 12 anos de idade. Era, portanto, uma imigração de mão de obra em faixa produtiva e daqueles que já deveriam ter tido acesso à escolarização básica em Portugal, em grande parte. Também é preciso lembrar que a distribuição dos imigrantes era mais equilibrada no tocante à instrução: $57,48 \%$ eram analfabetos e $42,52 \%$ alfabetizados, indicando que não eram só portugueses sem instrução que entravam no território paulista, mas também que havia muitos analfabetos em Portugal (D.T.C.I., 1937).

Tais fatos permitem compreender essa medida aparentemente "estranha" tomada pela "colônia” portuguesa em Sáo Paulo, propondo a criação, em 1925, 
da Liga Propulsora da Instrução em Portugal. Os objetivos da Liga eram bem claros quanto à preocupação com o campo educacional português:

A Liga Propulsora da Instrução em Portugal tem como seus fins principais: cooperar, em nome do princípio da igualdade para pôr ao alcance de todos a instrução primária em Portugal; dotar as aldeias, vilas e cidades do país, começando pelas mais afastadas dos centros principais e pelas menos beneficiadas em relação àquele ensino, com edifícios escolares higiênicos e modernos (Revista Portuguesa, 1929:341).

A Liga publicava na época apelos para conseguir a contribuição dos compatriotas. Teria construído "cinco belos edifícios escolares" em Portugal, pretendendo construir outros mais. Para tanto, contou com donativos da colônia portuguesa de São Paulo, que totalizaram em 1925 o montante de 6 mil e 500 contos de réis, "uma grande fortuna nesse tempo" (80 Anos, 1992:103).

Podemos supor que a Liga tinha certamente sua razão de ser para os que vieram para o Brasil e já tinham conseguido certos recursos, mas que continuavam estreitamente ligados ao país de origem e preocupados com o sistema educacional precário que atingia grande parte das famílias dos imigrantes. Nas entrevistas que realizamos com imigrantes que vieram neste período, pudemos constatar tal precariedade, assim como o fato de que muitas crianças ficavam em Portugal quando os pais vinham para cá (Demartini, 2006b, 2010).

Além das instituições econômicas, culturais e educacionais, também foi criada durante a Primeira República a Associação Portuguesa de Esporte em 1920, depois denominada Associação Portuguesa de Desportos.

Com a democratização do futebol, após a Primeira Guerra Mundial, muitos times surgiram. Em 1901 cria-se a Liga Paulista de Futebol e o primeiro clube português a fazer parte da primeira divisão da Liga foi o Lusitano, em 1914. A Associação Portuguesa de Esportes foi criada em 14 de agosto de 1920, data da batalha Aljubarrota, quando Portugal se desligou do reino de Castela (Espanha). A partir de 1940 passou a chamar-se Associação Portuguesa de Desportos.

Como no futebol de São Paulo existiam regras para times participarem dos campeonatos organizados pela Liga e a Portuguesa náo possuía condições de disputar campeonatos, foi entáo realizada uma junçáo entre a Portuguesa e o 
Mackenzie, em 1920, que criou condiçôes para disputar campeonatos com o nome Portuguesa-Mackenzie. Este acordo durou até 1923, quando definitivamente desapareceu o Mackenzie, e entrou para a camisa a Cruz de Aviz. A Associação foi criada da reuniáo de cinco clubes de futebol existentes em São Paulo: Cinco de Outubro, Portugal Marinhense, Lusíadas, Marques de Pombal e o Lusitano. Atualmente, a Associação é carinhosamente chamada de Lusa.

Além do futebol, a Portuguesa possui diversos setores internos onde a tradição e cultura portuguesa estão presentes.

As observaçóes a que chegamos na pesquisa em que procuramos entrevistar pessoas das famílias de portugueses que chegaram a São Paulo ainda na Primeira República, considerando a diversidade de atividades por elas desempenhadas nesta metrópole, permitem-nos exemplificar as vivências familiares nesse período. Certamente não foi possível abranger todas as atividades que foram citadas anteriormente, especialmente entre os que fizeram fortuna, mas acreditamos que conseguimos fugir do estereótipo do "português pobre e rural" ou do "dono de armazém", na medida em que, já na primeira geração, constatamos a existência de ocupaçóes as mais variadas.

Observando os relatos sobre as atividades das várias famílias entrevistadas, podemos inicialmente anotar que apenas uma parte dos imigrantes que se fixaram em Sáo Paulo eram agricultores em Portugal; eram, geralmente, os que estavam em piores condiçóes, passando dificuldades. Vieram, como afirma Martins (1999:4), para "escapar da miséria".

É interessante notar que algumas famílias continuaram desenvolvendo atividades de plantio e criação na área metropolitana como forma de sobrevivência. Em outros casos, embora saindo de atividades agrárias que exerciam em Portugal, os imigrantes procuraram diversificar suas atividades, muitos deles passando a trabalhar por conta própria ou como empregados no comércio, como nos foi relatado por alguns entrevistados.

Havia também os que já tinham algumas atividades ligadas à fabricação e venda de produtos tais como rolhas de cortiça e vinho; nestes casos, também as dificuldades nos negócios os impeliram à emigração; em São Paulo, conseguiram montar seus próprios negócios. Em duas famílias a geração mais velha era ligada a atividades militares, mas chegando a São Paulo um imigrante foi para o interior trabalhar na agricultura, e outro começou a trabalhar de vendedor (é preciso notar que, na capital, consta de documentos que o trabalho 
em atividades de policiamento foi muito procurado e exercido por imigrantes portugueses).

Em condiçôes na chegada muito diferentes, pois dispondo de capital cultural, social e econômico, também vieram advogados, engenheiros, artesãos, que conseguiram estabelecer relaçóes com pessoas socialmente bem posicionadas em São Paulo, o que permitiu a vários deles conseguir trabalhos mais rapidamente e de acordo com sua formação. $\mathrm{O}$ fato de terem formação de nível superior também permitiu a inserção de alguns deles no campo educacional, com reconhecida atuação nesta área.

Mas também foi mencionado pelos familiares o caso de um imigrante que não tinha profissão "reconhecida" em Portugal, vivia de apostas de jogos. No Brasil, sua trajetória também foi incerta, como foi relatado.

O que é interessante destacar é que as profissóes exercidas por filhos e netos (segunda e terceira geraçóes) em vários casos acompanharam as profissóes da primeira geração, seja a que exerciam em Portugal, ou a que passaram a exercer no Brasil. Poder-se-ia pensar que se constituíram em "profissóes de família”, passadas de uma geração para outra. Não temos elementos para verificar como esta "transmissáo" se deu, mas se pode perceber pelos relatos que estas ocupaçóes eram valorizadas pelos que as detinham, mesmo quando náo lhes rendia muitos ganhos.

Em outros casos o fato de os membros da segunda geração já poderem cursar o nível superior ou cursos técnicos em São Paulo levou a mudanças grandes nas profissóes desempenhadas de uma geração para outra.

$\mathrm{Na}$ terceira geração, em quase todas as famílias, mesmo quando continuavam ligadas às profissões da primeira geração, vê-se que para exercê-las frequentaram algum curso de nível superior. Assim, os que continuaram no ramo dos negócios imobiliários, do comércio de flores, de joias etc., cursaram administração de empresas ou economia, especialmente os filhos (homens). Para as mulheres, nem sempre o curso foi o mesmo de seus irmãos, mesmo quando ajudavam nos negócios da família.

Em vários casos, entretanto, os da terceira geração mudaram para outras áreas depois do curso superior: tornaram-se, muitos, profissionais liberais (médicos, economistas, decoradores, psicólogos, analistas etc.).

De modo qual, podemos afirmar que durante a Primeira República muitas famílias de imigrantes portugueses conseguiram concretizar em São Paulo seus 
objetivos de ascensão social, seja via econômica, seja via educacional. Ao mesmo tempo, foi nesse período que a "colônia" portuguesa criou entidades importantes representativas do grupo, algumas delas atuantes até os dias atuais.

\section{Referências}

80 ANOS da Câmara Portuguesa de Comércio de São Paulo: 1912-1992. São Paulo: Brasiliense, 1992.

ABREU, Teixeira de. Cambiantes da emigração portuguesa. Boletim da Câmara Portuguesa de Comércio, Induistria e Arte de São Paulo, São Paulo, v. 1, n. 11, p. 10, nov. 1916.

ALENCASTRO, Luis F. de; RENAUX, Maria L. Caras e modos dos migrantes e imigrantes. In: PINHEIRO, Paulo Sérgio et al. (Org.). História geral da civilização brasileira: o Brasil Republicano. 4. ed. Rio de Janeiro: Bertrand Brasil, 1990. s.p. (V. 2: Sociedade e instituiçôes, 1889-1930).

AZEVEDO, Célia M.M. Onda negra, medo branco: o negro no imaginário das elites, século XIX. Rio de Janeiro: Paz e Terra, 1987.

BASSANEZI, Maria. S.B. Imigraçóes internacionais no Brasil: um panorama histórico. In: PATARRA, N.L. (Coord.). Emigração e imigração internacionais no Brasil contemporâneo. 2. ed. Sáo Paulo: FNUAP, 1996. v. 1, p. 1-38.

ATLAS da População do Estado de São Paulo. Governo do Estado de São Paulo. São Paulo: Fundação Seade, 1991.

CAMARGO, José F. de. Crescimento da população no estado de São Paulo e seus aspectos econômicos. São Paulo: FFCL/USP, 1952. (Boletim; 153)

CAMPOS, Maria C.S.S. Imagens do imigrante português no meio rural paulista. In: ; ROCHA-TRINDADE, M.B. (Org.). Olhares lusos e brasileiros. São Paulo: Usina do Livro, 2003. p. 67-98.

DEMARTINI, Zeila de B.F. Educação entre imigrantes portugueses na Primeira República: "Um pé lá e outro cá". (no prelo, 2010).

. Famílias portuguesas em São Paulo na Primeira República. Cadernos Ceru (USP), São Paulo, v. 12, p. 161-169, 2001.

. Imigrantes portugueses em São Paulo: algumas questôes sobre a inserção no campo econômico. Convergência Lusiada, Rio de Janeiro, v. 19, n. especial, p. 413-430, 2002.

Immigration in Brazil: the insertion of different groups. Journal of Immigrant \& Refugee Studies, v. 4, p. 69-95, 2006 a.

. Infância e imigração: Questôes para pesquisa. In: FREITAS, Marcos Cezar 
(Org.). Desigualdade social e diversidade cultural na infância e na juventude. São Paulo: Cortez, 2006b. p. 113-153.

- Migraçóes e relatos orais: as potencialidades das entrevistas com geraçóes sucessivas. In: ROCHA-TRINDADE, Maria Beatriz; CAMPOS, Maria Christina Siqueira de Souza (Org.). Olhares lusos e brasileiros. São Paulo: Usina do Livro, 2003. p. 157-178.

. O coronelismo e a educação na Primeira República. Educação \& Sociedade, São Paulo, ano X, n. 34, p. 44-74, 1989.

; ESPÓSITO, Yara L. São Paulo no início do século e suas escolas diferenciadas. Ciência e Cultura, São Paulo, v. 41, n. 10, p. 981-995, out. 1989.

D.T.C.I. Estatística de imigração. São Paulo: Departamento de Imigração e Colonização/Secretaria da Agricultura do Estado de São Paulo, 1916.

. Estatística de imigração. São Paulo: Departamento de Imigração e Colonização/ Secretaria da Agricultura do Estado de São Paulo, 1937.

FAUSTO, Boris. Trabalho urbano e conflito social (1890-1920). São Paulo: Difel, 1976. (Corpo de Alma do Brasil)

FRUTUOSO, Maria S.G. Emigração portuguesa e sua influência no Brasil: o caso de Santos, 1850 a 1950. Dissertação (mestrado) — Faculdade de Filosofia, Letras e Ciências Humanas, Universidade de São Paulo, São Paulo, 1989.

IANNI, Octavio. O progresso econômico e o trabalhador livre. In: HOLANDA, Sérgio B. (Org.). história geral da civilização brasileira. São Paulo: Difel, 1967.

LANG, Alice. B.S.G. A propaganda republicana na Província de São Paulo. São Paulo: Ceru/USP, 1995. (Textos, série 2, n. 6)

. Portugueses em São Paulo: memória e identidade. In: CAMPOS, M.C.S.S.; ROCHA-TRINDADE, M.B. (Org.). Olhares lusos e brasileiros. São Paulo: Usina do Livro, 2003. p. 99-130.

LEVY, Maria Stela F. O papel da migração internacional na evolução da população brasileira 1872-1972. Revista de Saúde Pública, n. 8 (supl.), 1974.

LISBOA, Maria A.M. A política dos coronéis e a difusão do ensino primário em Angatuba/SP (1870-1930). 532 f. Tese (doutorado em educação) — Faculdade de Educação, Universidade Estadual de Campinas, Campinas, 2008.

MARTINS, José S. Transcrição de fala do autor em uma mesa-redonda. São Paulo: USP, 1999.

PRADO JR., Caio. História econômica do Brasil. 3. ed. São Paulo: Brasiliense, 1953.

PETRONE, Maria T.S.I. In: PINHEIRO, Paulo S. et al. (Org.). História geral da civilização brasileira: o Brasil Republicano. 4. ed. Rio de Janeiro: Bertrand Brasil, 1990. v. 2: Sociedade e Instruçóes: 1889-1930, p. 93-133. 
REVISTA Portuguesa. s.l.: s.n., [1929].

RIBEIRO, Gladys S. Mata galegos: os portugueses e os conflitos de trabalho na República Velha. São Paulo: Brasiliense, 1990.

RIBEIRO, Maria J.F.A. Memória, imigração e educação: Fábrica de Tecidos Carioba: uma vila industrial paulista no início do século XX. $230 \mathrm{f}$. Tese (doutorado em educação) — Faculdade de Educação, Universidade Estadual de Campinas, Campinas, 2005.

SERRÃO, Joel. A emigração portuguesa: sondagem histórica. Lisboa: Livros Horizonte, 1971.

SILVA, Maria B.N. da. Documentos para a história da imigração portuguesa no Brasil, 1850-1938. Rio de Janeiro: Editorial Nórdica, 1992.

SILVA, Sérgio. Expansão cafeeira e origens da induistria no Brasil. São Paulo: Alfa-Ômega, 1960.

VAINER, Carlos B. Estudo e migração internacional no Brasil: da imigração à emigração. In: PATARRA, Neide (Coord.). Emigração e imigração internacionais no Brasil contemporâneo. 2. ed. São Paulo: FNUAP, 1996.

XAVIER, Leonor. Contributo para a história dos portugueses no Brasil: relato de uma experiência profissional luso-brasileira. São Paulo: Secretaria do Estado da Imigração, s.d. 